\title{
Ecological Significance of Microdiversity: Coexistence Among Casing Soil Bacterial Strains Through Allocation of Nutritional Resource
}

\author{
Devendra Kumar Choudhary • Bhavdish N. Johri
}

Received: 2 April 2008/Accepted: 2 September 2009/Published online: 26 January 2011 (C) Association of Microbiologists of India 2011

\begin{abstract}
A combination of cultivation-based methods with a molecular biological approach was employed to investigate whether bacteria with identical $16 \mathrm{~S}$ rRNA gene sequences can represent distinct eco- and genotypes. A set of eight bacterial strains wherein three were Pseudomonas putida and rest were Acinetobacter calcoaceticus, were isolated from casing soils community by conventior 1 plating. These strains had identical 16S rRNA gen sequences and represented the dominant phylotyp in the plateable fraction. Each strain utilized a specinc nibination of 154 carbon substrates, and the riche on indices were low, suggesting that each st a ccupied a different ecological niche. Our results ha implic ons for assessment of the diversity and bio eography of bacteria and increase the perception of nat al dive sity beyond the level of $16 \mathrm{~S}$ rRNA gene sequenc. is worthwhile approach to explore prokary diversity in different ecological niches.

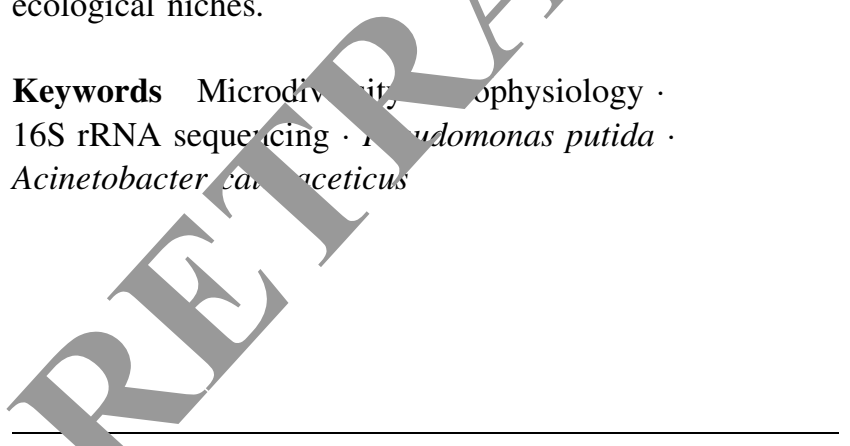

D. K. $\triangle$ udhary $(\bowtie)$

Department of Science, Faculty of Arts, Science \& Commerce (FASC), Mody Institute of Technology \& Science (MITS), Lakshmangarh, Sikar, Rajasthan 332311, India

e-mail: devmicro@rediffmail.com

\section{B. N. Johri}

Department of Biotechnology \& Bioinformatics Centre, Barkatullah University, Bhopal, MP 462026, India

\section{Introduct}

Mumt Iımbo, nat is how Thomas Brock [1] described the stucy ${ }_{1}$, ersity in his pithy and prescient essay on the state of microbial ecology in 1987. Brock argued that measures of diversity were pointless because the dynamic ure of the microbial world meant that communities did no have a characteristic diversity but changed as the nvironment changed. Wilson [2] reinforced the futility of the study of microbial diversity when he observed that microbial diversity is 'beyond practical calculation'. The rationale for low prokaryotic diversity is that microbial organisms are so abundant, that free-living representatives can be easily globally dispersed. Consequently allopatric speciation is discouraged in microbial communities by very high invasion rates [3]. Curtis et al. [4] developed a rough and ready universal prokaryotic diversity estimator. They used published data on rRNA gene based clone libraries and found that there could be 7,000 species in a gram of soil. Thus, a ton of soil could theoretically hold 3 million different taxa. The relationship between structure and function in a community can only be understood, predicted and engineered through an understanding of the source of diversity from which the community is drawn [5].

Analysis of 16S rRNA (ribosomal RNA) gene sequences has become the primary approach for studying the natural occurrence and distribution of bacteria in a culture independent manner [6]. The vertical and seasonal distributions of distinct $16 \mathrm{~S}$ rRNA gene sequences (phylotypes) within one ecosystem have been used to infer the ecological niches of bacteria [7, 8]. This approach is especially valuable if the physiology of bacteria that have not been cultured yet is to be elucidated.

In many cases phylogenetically closely related bacteria (whose $16 \mathrm{~S}$ rRNA sequences differ by between 2.7 and $0.3 \%$ ) 
have been detected in the same fresh water, marine, or soil habitat [8]. According to macroecological principles of competitive exclusion, physiologically similar micro organisms should not co-occur in nutrient poor systems which are dominated by physical and chemical fluctuations [7]. Accordingly, phylogenetically closely related bacteria coexisting in the same habitat occupy distinct ecological niches which make up the microdiversity [8-11]. For pathogenic bacteria it is well established that even phylogenetically identical strains or species can exhibit distinct ecophysiological properties. Certain serovars of Mycobacterium intracellulare [12], serovars of Ochrobactrum anthropi [13], strains of Yersinia pestis, Yerinia pseudo tuberculosis [14], or strains of Bacillus anthracis, Bacillus cereus [15], contain identical $16 \mathrm{~S}$ rRNA gene sequences. These phylogenetically identical organisms are also genetically highly similar based on DNADNA hybridization data but clearly represent different ecotypes based on their virulence properties or host ranges. Often, phenotypic differences can be traced back to the presence of plasmids, as in $B$. anthracis, in which the major virulence determinants are encoded by the $181-\mathrm{kb}$ plasmid $\mathrm{pX} 01$ and the 95-kb plasmid pX02 not present in B. cereus [16].

In the present study, eight bacterial strains were selected wherein three were Pseudomonas putida and rest five strains were Acinetobacter calcoaceticus with identir 1 $16 \mathrm{~S}$ rRNA gene sequences. All bacterial strains were iso lated from mushroom casing soil (an integrated part of mushroom compost ecosystem and used for cula, in of button mushroom). The strains were subseque itly ana. with respect to their genomic and physiolo gic. diversities, and their ecological niches.

\section{Materials and Methods}

Recovery of Bacterial Strains

Casing sample (10 g)
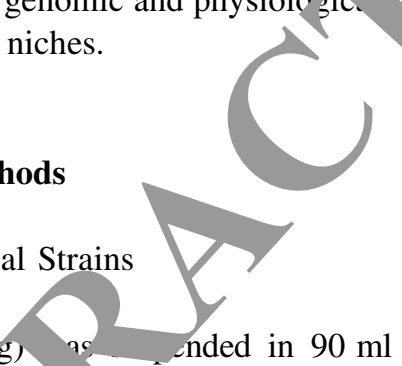

normal sain ( $18^{\circ} \mathrm{C}$ for $1 \mathrm{~h}$. T $\mathrm{e}$, lting shurry was serially diluted $(100 \mu \mathrm{l})$ to $900 \mu \mathrm{l}$ of $\mathrm{85} \%$ no 1 saline in each Eppendorf tube and appropri e dilution $\left(10^{-4}\right)$ of this suspension $(100 \mu \mathrm{l})$ was spread plà. 'n tri icate, on King's B medium [17]. Cultures wer ubate $20^{\circ} \mathrm{C} \pm 2$ for 2 days. After incubation they re re ${ }^{2}$ d until pure cultures were obtained. The purity of a trains isolated was examined microscopically. For experin,ental use, isolates were transferred when needed to King's B medium that was stored at $4^{\circ} \mathrm{C}$.

\section{DNA Extraction}

For total genomic DNA extraction [18] $1.5 \mathrm{ml}$ culture was centrifuged at $12,000 \mathrm{rpm}$ for $10 \mathrm{~min}$ at $4{ }^{\circ} \mathrm{C}$; the pellet was washed with $1.5 \mathrm{ml}$ of TRIS-Cl $(0.1 \mathrm{M}, \mathrm{pH} 6.8)$ twice and centrifuged. Cells were lysed with a combination of $0.5 \%$ SDS and $0.001 \%$ proteinase $\mathrm{K}$ followed by treatment with $1 \%$ CTAB and washed with phenol: chloroform (1:1) and chloroform: isoamyl alcohol (24:1). DNA was precipitated with absolute alcohol at $-20^{\circ} \mathrm{C}$ overnight followed by pelleting and washing with $70 \%$ ethanol Aiter RNAse treatment, pellet was checked for prese. DVA on $0.8 \%$ agarose gel run in TBE buffer at $70 \mathrm{~V}$ to 5 min. Gel was stained with ethidium bromid and visualized under UV on a Gel Doc Mega System Bio tem cica.

Quantification and Detection f Purity of Extracted DNA

Extracted genomic $\mathrm{D} A$ was run $10.8 \%$ agarose gel at $80 \mathrm{~V}$ for 45 min with quan tatı narker in one lane (Low DNA Mass Ladder, MBI entas). Cel was visualized under UV transilluminator. A quantified spectrophotometrically, by measuring OD 260 and $280 \mathrm{~nm}$. Purity of DNA was checked measu the ext, iction at $\mathrm{A}_{260} / \mathrm{A}_{280}$, on a DU $640 \mathrm{~B}$ Beckman spectro ho un ier. The concentration of DNA was calculated as: $\left[\right.$ DNA $=\mathrm{A}_{260} \times 100 \times$ Dilution factor $\left(\mu \mathrm{g} \mathrm{ml}^{-1}\right)$.

R Amplification of 16S rDNA

the amplified 16S rRNA gene was obtained from each bacterial isolate by PCR amplification employing the eubacterial universal primers [19] fDI (5'-AGAGTTTGA TCCTGG- $\left.3^{\prime}\right)$ and rP2 (5'-TACCTTGTTACGACTT- $\left.3^{\prime}\right)$ which were targeted at universally conserved regions and permitted amplification of approximately 1,500-bp fragment. PCR amplification was carried out in a PTC-100 thermocycler (M.J. Research). Reaction tubes contained $25 \mathrm{ng}(5 \mu \mathrm{l})$ of DNA extract, $1 \mathrm{U}$ of Taq polymerase (Genei), $1 \times$ buffer $(10 \mathrm{mM}$ Tris-Chloride [pH 9.0], $1.5 \mathrm{mM}$ $\mathrm{MgCl}_{2}, 500 \mathrm{mM} \mathrm{KCl}$ ) (Genei), $10 \mathrm{mM}$ dNTPs (Genei) and $0.25 \mathrm{mM}$ of each primer (Genei). Initial DNA-denaturation and enzyme activation steps were performed at $95^{\circ} \mathrm{C}$ for $7 \mathrm{~min}$, followed by 25 cycles of denaturation at $94^{\circ} \mathrm{C}$ for $1 \mathrm{~min}$, annealing at $51^{\circ} \mathrm{C}$ for $1 \mathrm{~min}$ and extension at $72^{\circ} \mathrm{C}$ for $1 \mathrm{~min}$, and a final extraction at $72^{\circ} \mathrm{C}$ for $10 \mathrm{~min}$. The presence and yield of specific PCR product (16S rRNA gene) was monitored on $0.8 \%$ agarose (wt/vol.) (Life Technologies Inc.); gel electrophoresis was carried out at $100 \mathrm{~V}$ for $30 \mathrm{~min}$ in $1 \times$ Tris-acetate-EDTA buffer and visualization by ethidium bromide staining and viewing on a UV transilluminator (Biosystematica).

Partial Sequencing of the $16 \mathrm{~S}$ rDNA

PCR products obtained from bacterial strains were purified with an EXO-SAP. Components were supplemented with 
gold buffer (Applied Biosystem) and sequenced on an Applied Biosystem 310 Genetic analyzer, using big dye terminator cycle sequencing Ready Kit (Lab India). The partial sequences amplified by the fDI primer were used to determine the similarities.

\section{Nucleotide Sequence Accession Numbers}

The partial 16S rRNA gene sequences of strains determined in this study have been deposited in the GenBank database of NCBI under accession numbers (parentheses): UVC 2 (AY 961043), CVC 2 (AY 967724), USC 31 (DQ 074752), UVC 4 (AY 961045), UVC 3 (AY 961044), UVC 8 (AY 961047), USC 29 (AY 961061) and USC 30 (DQ 074751).

\section{Sole Source Carbon Utilization (SSCU)}

The bacterial strains were tested for their ability to catabolize 154 different compounds (see Table 1) as sole carbon sources at a concentration of $5 \mathrm{mM}$ each. Bacterial strains were cultured on $\mathrm{KB}$ for $18 \mathrm{~h}$ at $20^{\circ} \mathrm{C}$. Bacterial cells were scraped from the plate and suspended in phosphate buffer (0.01 M, pH 7.0). The cell suspensions were adjusted to optical density at $560 \mathrm{~nm}, 0.12$. For growth tests, ea h microtitre well received triplicate $180 \mu \mathrm{l}$ of minima medium (M9) and was inoculated with $15 \mu \mathrm{l}$ of a bacterial suspension, and $10 \mu \mathrm{l}$ of redox dye, triphenyl-tetrazolium chloride (TTC). Control well was devoid of bacterial suspension. The plates were incubated for 5 days at $20^{\circ} \mathrm{C}$, and growth was monitored by determining the colour change of dye from colourless to red.

\section{Niche Overlap Index (NOI)}

The NOI was defined in this study the number of carbon sources utilized by both strains as a $\mathrm{A}$ norti $n$ of the total number of carbon sources uti zed by the crain in question $\left(\mathrm{N}_{\text {tot }}\right): \mathrm{NOI}=\mathrm{N}_{\mathrm{A} \cap \mathrm{B}} / \mathrm{N}_{\text {tot }}[20$

Physiological Similar:y

The physiological sin rity of the eight bacterial strains was determin - y cluste, analysis. A matrix with a binary code for th res or absence of each phenotypic trait of the isolate wa onstructed. The Jaccard coefficient for all pairs ctrains yas calculated employing the SIMQUAL similarity pramme for qualitative data of the NTSYS-pc numerica 1 taxonomy computer package [21]. Cluster analysis was performed with the SAHN program of the SYS-pc package and by employing the unweighted pair gr up method with arithmetic average (UPGMA).

Table 1 Compound tested for eight strains bel gea Pseudomonas putida and Acinetobacter calcoaceticus, for their ability to supports growth of the bacterial strains on sole source jubon util ion (SSCU) when incorporated into minimal medium

\begin{tabular}{|c|c|}
\hline Type & Compounds \\
\hline Amino acids & $\begin{array}{l}\text { D-Alanine, L-alanine, L-ala. } \\
\text { L-glutamine, L-g } \\
\text { L-isoleucine, L-leıcin glycyl-L-aspartic acid, glycyl-L-glutamic acid, L-histidine, L-homoserine, hydroxy-L-proline, } \\
\text { tryptoph }\end{array}$ \\
\hline Organic acids & $\begin{array}{l}\text { Adipic cid, etic ac d, aconitic acid, anthranilic acid, } \alpha \text {-aminobutyric acid, } \gamma \text {-aminobutyric acid, citraconic acid, citric acid, } \\
\text { folic a } \\
\text { gluconic glucuronic acid, glucosaminic acid, glutaric acid, glyceric acid, glycolic acid, } \alpha \text {-hydroxybutyric acid, } \\
\text { hydroxyb, atyric acid, } \gamma \text {-hydroxybutyric acid, hyroxyphenylacetic acid, itaconic acid, } \alpha \text {-ketobutyric acid, } \alpha \text {-ketoglutaric } \\
\text { ac } \alpha \text {-ketovaleric acid, lactic acid, malic acid, maleic acid, malonic acid, methylpyruvic acid, monomethylsuccinic acid, } \\
\text { muck dcid, nicotinic acid, para-aminobenzoic acid, pantothenic acid, pimelic acid, pipe-colic acid, propionic acid, pyruvic } \\
\text { acid, quinic acid, saccharic acid, salicylic acid, sebacic add, shikimic acid, succinic acid, bromosuccinic acid, succinamic } \\
\text { id, tartaric acid, urocanic acid }\end{array}$ \\
\hline & $\begin{array}{l}\text { Amylose, arabinose, cellobiose, cyclodextrin, dextran, dextrin, fructose, fucose, furanose, galactose, gentiobiose, glucose, } \\
\text { glucose 1-phosphate, glucose 6-phosphate, glycogen, lactose, lactulose, maltose, mannose, melezitose, melibiose, } \\
\text { palatinose, psicose, raffinose, rhamnose, ribose, sorbose, starch, sucrose, trehalose, xylose }\end{array}$ \\
\hline Sugar a hols & Adonitol, arabitol, dulcitol, erythritol, inositol, mannitol, sorbitol, xylitol \\
\hline $\begin{array}{l}\text { Amides and } \\
\text { amines }\end{array}$ & Acetamide, $N$-acetyl-D-glucosamine, $N$-acetyl-D-galactosamine, alaninamide, glucuronamide, phenylethylamine \\
\hline Alcohols & 2,3-Butanediol, ethanol, 2-aminoethanol, DL- $\alpha$-glycerolphosphate, glycerol, methanol \\
\hline Fatty acids & Capric acid, caproic acid, caprylic acid, lauric acid, lauryl sulfate, levulinic acid, myristic acid \\
\hline Miscellaneous & $\begin{array}{l}\text { Betaine, DL-carnitine, choline chloride, inosine, } \beta \text {-methylglucoside, ornithine, putrescine, salicin, sarcosine, thymidine, } \\
\text { Tween 40, Tween } 80\end{array}$ \\
\hline
\end{tabular}




\section{Results}

Colour Formation in Microtiter Plates

Development of redox sensitive dyes such as TTC and incorporation of these dyes into microtiter plates has allowed for rapid profiling of sole source carbon utilization by bacterial isolates [22]. Colour formation in microplate wells in SSCU is based on the conversion of the redoxsensitive tetrazolium dye which is reduced during respiratory activity, and accumulates as insoluble formazan inside active cells. No colour development was observed in the control well.

\section{Ecological Similarity and Co-Existence}

Strains were morphotypically quite similar and they were Pseudomonas putida and Acinetobacter calcoaceticus species based on partial 16S rRNA gene sequencing. Consequently, their potential ecological niches were assessed based on their carbon substrate utilization patterns.

Each strain used a unique combination of the 154 carbon substrates. The lowest metabolic diversity was observed for strain USC 31 ( $P$. putida) isolated from FYM + SC (3:1) whereas it was higher for two strains of $P$. putida viz, UV 2 and CVC 2. The higher NOI calculated for all pairs 0 $P$. putida strains indicated that they occupy differ-nt ecological niches i.e. cannot coexist. Similarly, NO all pairs of A. calcoaceticus strains was calculat d (Tab.

\section{Compositional Similarity}

Measure of niche overlap index (N I) does not provide information about the types of substrat are utilized by the bacterial strains. Four st howed identical NOI

Table 2 NOIs for casing oil cterial trains, derived from carbon source utilization

\begin{tabular}{|c|c|c|c|c|}
\hline Strains $^{\mathrm{a}}$ & & acids & $\begin{array}{l}\text { Organic } \\
\text { acids }\end{array}$ & Carbohydrates \\
\hline & & 0.889 & 0.870 & 1.000 \\
\hline & $0 ., 08$ & 0.960 & 1.000 & 0.875 \\
\hline 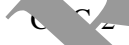 & 0.945 & 0.942 & 0.933 & 1.000 \\
\hline UVC 3 & 0.904 & 1.000 & 1.000 & 0.962 \\
\hline UVC 4 & 0.954 & 0.989 & 0.900 & 1.000 \\
\hline UVC 8 & 0.908 & 1.000 & 1.000 & 0.915 \\
\hline USC 29 & 0.877 & 1.000 & 0.983 & 1.000 \\
\hline USC 30 & 0.965 & 0.988 & 1.000 & 1.000 \\
\hline
\end{tabular}

${ }^{\mathrm{a}}$ NOIs for pair of strains

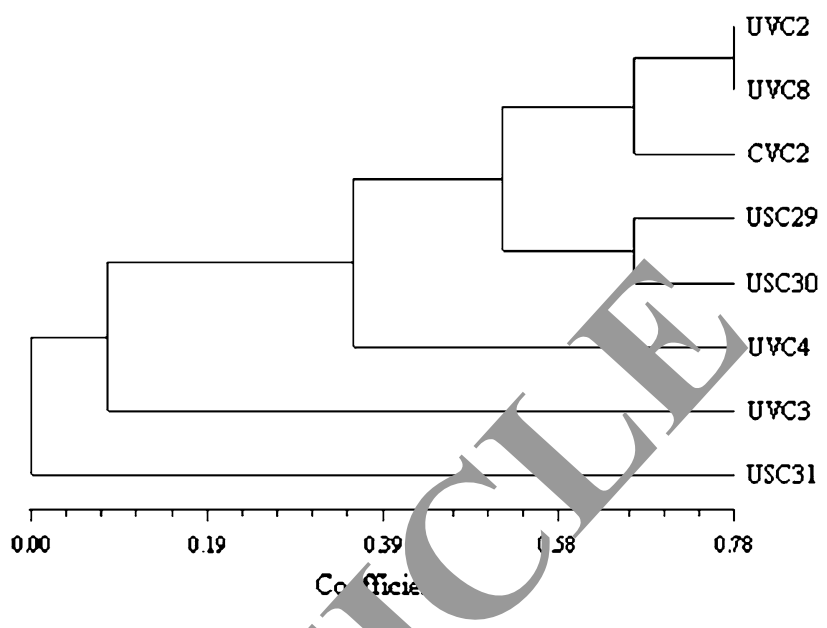

Fig. 1 Physiological sir 11 arity a rains of the species Pseudomonas putida and Acinetobo. calcoace, cus, assessed by cluster analysis based on the sut trate tilization patterns employing Jaccard coefficient

but still cata lized different substrates. Beside NOI, a consis ant relatio ship among strains was made by cluster analysis, on the presence or absence of substrate utilized Fig. 1). Two strains UVC 2 and UVC 8 showed $78 \%$ simuarity and they had $65 \%$ similarity with CVC 2 ereas USC 29 and USC 30 showed $65 \%$ similarity with ea $h$ other. The least relationship was observed for UVC 4, VC 3 and USC 31 with each other. Strain USC 31 was entirely different i.e. different and had least no of substrates utilization by USC 31 while UVC 3 utilized quite more no of C-sources. They showed $15 \%$ similarity with UVC 4 and UVC 4 had $40 \%$ similarity with each other.

\section{Discussion}

It is important to study microbial diversity not only for basic scientific research, but also to understand the link between diversity and community structure and function. Although methods to study diversity (numerical, taxonomic, and structural) are improving for both bacteria and fungi, there is still not a clear association between diversity and function. Even if an organism is functionally redundant in one function, chances are it is not redundant in all functions and will have different susceptibilities and tolerances to abiotic and biotic stresses. It is generally thought that a diverse population of organisms will be more resilient to stress and more capable of adapting to environmental changes [23].

The Pseudomonas and Acinetobacter sp. strains investigated in the present study were retrieved from the casing soils. Therefore, a hitherto unknown multitude of ecotypes must thrive in the same habitat. Based on our results, it has to be concluded that the extent of genomic and 
physiological diversity masked by identical 16S rRNA sequences is much larger than has been assumed previously and that this so-called microdiversity has ecological relevance. If a bacterial species is defined as a "monophyletic and genomically coherent cluster of individual bacteria that show a high degree of overall similarity in many independent characteristics", then bacterial diversity may indeed exceed present estimates by several order of magnitude, as previously suggested [24, 25]. Wilson and Lindow [20] calculated niche overlap index for ice-nucleating $\left(\right.$ Ice $^{+}$) $P$. syringae strain with respect to non-ice-nucleating (Ice ${ }^{-}$) $P$. syringae strain TLP2 del. It was uniformly high indicating that they were ecologically similar but had low level of coexistence. These authors reported that in the phyllosphere resource partitioning among different bacterial species with NOI values of $0.25-0.59$ allowed stable coexistence, whereas catabolically identical strains (NOI 1.0 ), even if they belong to different species, cannot coexist.

Jaspers and Overmann [26] used a combination of cultivation based methods with nine molecular biological approaches to investigate whether planktonic bacteria with identical 16S rRNA gene sequences can represent distinct eco and genotypes. They isolated 11 strains of Brevundimonas alba from a freshwater community by employing conventional plating and MPN dilution series. All the 1 strains had identical 16S rRNA gene sequences and each. strain utilized a specific combination of 59 C-syostrates and the NOI were low which suggested that ea cain occupied different ecological niche.

The genomes of certain phylogene ica identical strains exhibit profound differences. Eso richia $\% \mathrm{~K}-12$ and 0157:H7 differ not only in geno ne size (by $0.89 \mathrm{Mb}$ ) but also in a considerable number o hromo omal genes. Twenty-five percent of the genes pro in the enterohemorrhagic organism E.coli 0 r are not found in the nonpathogenic organism E. coli $\mathrm{K} / 2$, whereas $12 \%$ of the genes in the latter o gar $\mathrm{m}$ ar $/$ absent in the former organism [27]. Never , ne of the 16S rRNA gene sequences (e.g., the two $r$ genes) are identical in the two organisms. Sir ili. genomic fingerprinting [28-30] and analysis of fasmid liv :es of DNA fragments from marine samples 31] have indicated that nonpathogenic bacteria with iden 16, rRNA gene sequences but distinctly diff gen es coexist in natural ecosystems [24]. The t. n diversity has been used to describe the phenom on of phylogenetically closely related but physiologicaly distinct bacterial populations [9]. In order to assess the extent of microdiversity present in a natural habitat, the niche separation between the different genotypes with identical 16S-rRNA genes, and finally the potential limitations of 16S-rRNA-based methods, more information about the genetic and ecophysiological differences of such bacteria is required.
Acknowledgments This work was performed at Department of Biotechnology, BU, Bhopal with kind cooperation of Dr. Anil Prakash, Head, Department of Biotechnology \& Bioinformatics Centre, Bhopal.

\section{References}

1. Brock T (1987) The study of microorganish n situ: rogress and problems. In: Gray TRG, Jones JG (eds) Ec vo of microbial communities (Fletcher M. Car bridge Univ isity Press, Cambridge

2. Wilson EO (1994) The diversitv or life. ou h, London

3. Finlay BJ (2002) Global di persal of fie living microbial eukaryote species. Science 29 1061-10/3

4. Curtis TP, Sloan WT, S anne (2002) Estimating prokaryotic diversity its limits. Proc Acau sci USA 99:10494-10499

5. Curtis TP, Sloan V T (200 Prokaryotic diversity its limits: microbial comm structure an nature implications for microbial ecology. C. rr OH Microbiol 7:221-226

6. Amann R, rg W, Aleifer KH (1995) Phylogentic indentification nsitu detection of individual microbial cells without cultivation $\quad$ Rev 59:143-169

7. Pernthaler J, ckner FO, Unterholzner S, Altreider A, Psenner $\mathrm{R}$, ann R (1 98) Seasonal community population dynamics of pelagric fia and archaea in a high mountain lake. Appl Envir $n$ Microbiol 60:4299-4306

8. Ward DM, Ferris MJ, Nold SC, Bateson MM (1998) A natural view of microbial biodiversity within not spring cyanobacterial mat communities. Microbial Mol Biol Rev 62:1353-1370 Moore LR, Rocap G, Chisholm SW (1998) Physiology and molecular phylogeny of coexisting Prochlorococcus ecotypes. Nature 393:464-467

10. Postius C, Ernst A (1999) Mechanism of dominance: coexistence of picocyanobacterial genotypes in a freshwater ecosystem. Arch Microbiol 172:69-75

11. Gray ND, Head IN (2001) Linking genetic identities function in communities of uncultured bacteria. Environ Microbiol 3: 481-492

12. Böddinghaus B, Wolters J, Heikens W, Bottger EC (1990) Phyhogenetic analysis and identification of deferent serovars of Mycobacterium intracellulare at the molecular level. FEMS Microbiol Lett 70:197-204

13. Lebuhn M, Achourak W, Schloter M, Berge O, Meier H, Hartmann A, Heulin T (2000) Taxonomic characterization of Ochrobactrum sp. isolated from soil samples and wheat roots, and description of Ochrobactrum tritici $\mathrm{sp}$. nov. and Ochrobactrum grignunense sp. nov. Int J Syst Evol Microbiol 50:2207-2223

14. Trebesius K, Harmsen D, Rakin A, Schmelz J, Heesemann J (1998) Development of RNA targeted PCR in situ hybridization with fluorescently labeled oligonucleotides for detection of Yersinia species. J Clin Microbiol 36:2557-2564

15. Ash C, Farrow JAE, Dorsch M, Stackebrandt E, Collins MD (1991) Comparative analysis of B. anthracis, B. cereus and related species on the basis of reverse transcriptase sequencing 16S rRNA. Int J Syst Bacteriol 41:343-346

16. Read TD, Peterson SN, Tourasse N, Baillie LW, Paulsen IT, Nelson KE, Tettelin H, Fouts DE, Eisen JIA, Gill SR, Holtzapple EK, Okstad OA, Helgason E, Rilstone J, Wu M, Kolenay JF, Beanan MJ, Dedcon RJ, Brinkac LM, Gurinn M, Deboy RT, Madpu R, Daugherty SC, Durkin AS, Haft DH, Nelson WC, Peterson JD, Pep M, Khouri HM, Radune D, Benton JL, Mahamoud Y, Jiang L, Hance IR, Weidman JF, Berry KJ, Plant RD, Wolf AM, Watkins KL, Nierman WC, Hazen A, Cline R, Redmond C, Thwaite JE, White O, Salzberg SL, Thomason B, 
Friedlander AM, Kuchler TM, Hanna PC, Kslsto AB, Fraser CM (2003) The genome sequence of Bacillus anthracis Ames and comparison to closely related bacteria. Nature 423:81-86

17. King EO, Ward MK, Raney DE (1954) Two simple media for demonstration of pyocyanin and fluorescein. J Lab Clin Med 44:301-307

18. Bazzicalupo M, Fani R (1994) The use of RAPD for generating specific DNA probes for microorganisms. In: Clapp J (ed) Methods in molecular biology. Humana Press Inc, Totowa, pp 155-175

19. Weisburg WG, Barns SM, Pelletier DA, Lane DJ (1991) 16S ribosomal DNA amplification for phylogenetic study. J Bacteriol 173:697-703

20. Wilson M, Lindow SE (1994) Coexistence among epiphytic bacterial populations mediated through nutritional resource partitioning. Appl Environ Microbiol 60:4468-4477

21. Rohlf FJ (1993) NTSYSpc numerical taxonomy and multivariate analysis system for the IBM PC microcomputer (and compatibles). Applied Biostatistics, Setauket, NY

22. Bachner BR, Savagean MA (1977) Generalized indicator plate for genetic, metabolic and taxonomic studies with microorganisms. Appl Environ Microbiol 33:434-444

23. Kirk JL, Beaudette LA, Hart M, Moutoglis P, Klironomos JN, Lee H, Trevors JT (2004) Methods of studying soil microbial diversity. J Microbiol Methods 58:169-188

24. Rossellö-Mora R, Amann R (2001) The species concept for prokaryates. FEMS Microbiol Rev 25:39-67

25. Dykhuizen DE (1998) Santa Rosalia revisited: why are there so many species of bacteria? Antonie Van Leeuwen 73:25-33
26. Jaspers E, Overmann J (2004) Ecological significance of microdiversity: identical $16 \mathrm{~S}$ rRNA gene sequences can be found in bacteria with highly divergent genomes and ecophysiologies. Appl Environ Microbiol 70:4831-4839

27. Perna NT, Plunkett G III, Burland V, Man B, Glasner JD, Rose DJ, Mayhew GF, Evans PS, Gregor J, Kirkpatrick HA, Posfai G, Hackett J, Klink S, Boutin A, Shao Y, Miller L, Grotbeck EJ, Danis NW, Lim A, Dimalanta ET, Potamousis D, Apodaca J, Anantharaman TS, Lin J, Yen G, Schwart DC, Welch RA, Blattner FR (2001) Genome sequence of $r$ mem rrhagic E.coli 0157: 117. Nature 409:529-533

28. Sass H, Wieringa E, Cypionka H, Bøbenzien HD, Jvermann J (1998) High genetic physiological a sity of ylfate reducing bacteria isolated from oligotrophis..ke su nen . Arch Microbiol 170:243-251

29. Sikorski J, Nohle M, Wacke agel W 2002) Identification of complex composition, str ing s dive sity directional selection in local pseudomonas stu i popuntions from marine sediment and sials. Environ Microbio, 165-476

30. Wieringa EJ, Oy ann M, ypionka H (2000) Detection of abundant sulph te $\mathrm{h}$ ing bacteria in marine oxic sediment layers by ombinea ultivation and molecular approach. Environ Nicro ol 2:417-427

31. Beja G, Aravind L, Taylor LT, Seitz H, Stein JL, Bensen DC, ldman RA, Swanson RV, Dehong EF (2002) Co marative ge omic analysis of archeal genotypic variants in a sing 'e Ation in two different oceanic provinces. Appl Enviion Microbial 68:335-345

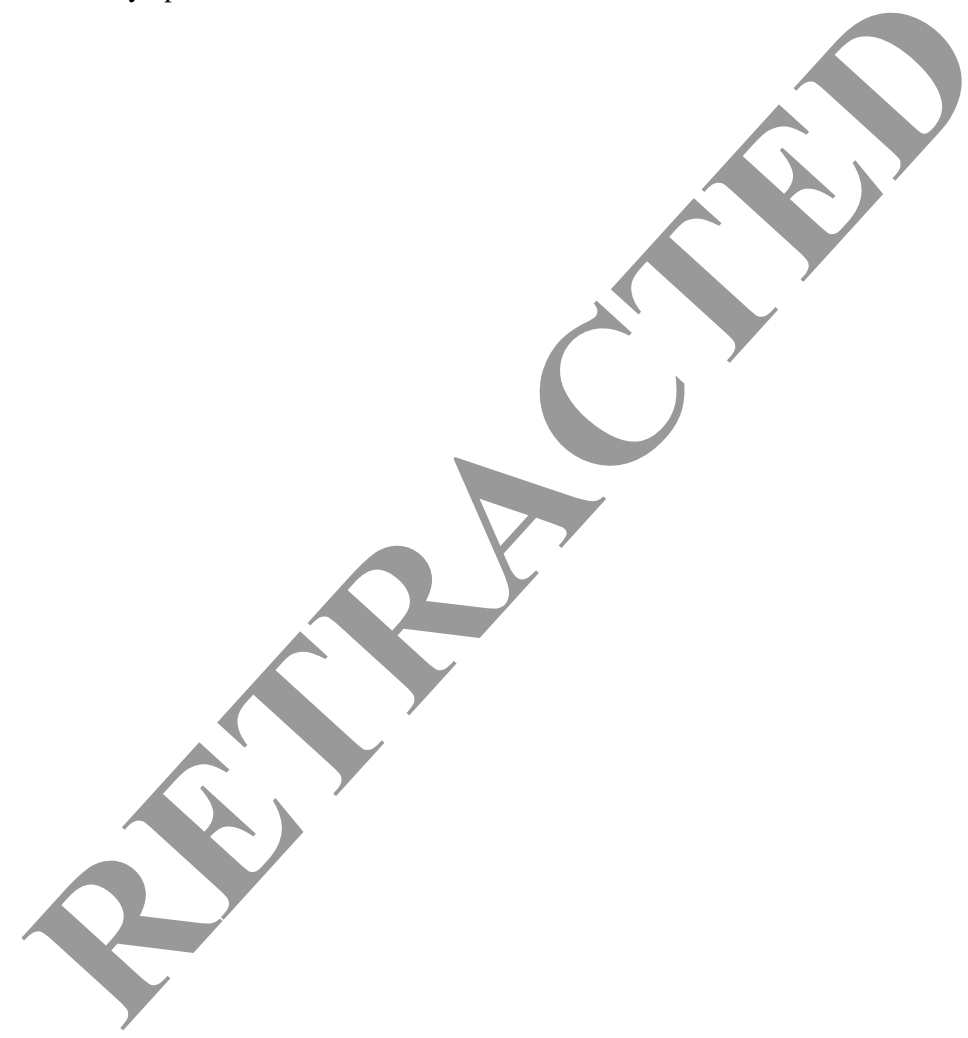

